\title{
PREFACE: WHY DIJON?
}

This book had its origin in the early 1990s when Robert Weiner became involved with the Jewish community of Dijon, a major provincial center in eastern France. His interest in this relatively small but unique society evolved into a long-term study. He knew that most published works about French Jews focused on the large Jewish population of Paris, yet nearly half of all French Jews live elsewhere in France. It was Weiner's purpose to provide insights into the lives of these "others" by immersing himself as much as possible in a community that had all the attributes of Jewish identity, that was representative of non-Parisian Jews, and yet that was distinctive in its own way.

This contemporary oral history, based on interviews and recorded observations made over an 18-year period, is the first of its kind, at least in English. The interviews, some repeated with the same subjects years later, provide a portrait of how this community evolved over time in response to challenges, both internal and external, and of the tensions that have brought about changes within it. These tensions include, to provide some examples, those between Jews who emigrated from Eastern Europe and North Africa; the traditional community and newly arrived Lubavitch Jews; Jews and non-Jews, including recent Muslim immigrants; the older and younger members; and intermarriage within and outside the community. Indeed, the interviews cover virtually every form of Jewish identity found in Dijon. They are complemented by several excerpts from the community journal, Mazal Tov, which provide the reader with an additional perspective.

The book will be of interest to the informed reader interested in contemporary Jewish life as well as to the student of Jewish and European history and sociology. Most issues that impact the modern world, from the effects of economic change to the ongoing problems of ethnic conflict and antiSemitism, are discussed in the interviews. More specifically, such questions as how to be both French and Jewish and how to be loyal at the same time to a secular nation as well as a separate spiritual homeland are asked and answered quite differently. In sum, the book provides fascinating personal accounts of those who experienced the renewal of a community from the catastrophe of the Holocaust through integration of a new culture to optimistic growth and expansion followed by division, slow decline, and uncertainty about the future. It is the story, written small, about other European Jewish communities and perhaps those elsewhere.

Weiner's interest in the Dijon Jewish community began somewhat informally in 1993 when he led a group of Lafayette College students on a 
semester-abroad program affiliated with a French language institute associated with the University of Burgundy in Dijon. He was aware, of course, that in the late 1980 s and early 1990 s there was a revival of interest in France in the Jewish experience and a resulting substantial production of both popular and scholarly writing. ${ }^{*}$ Most of this output, however, focused on Paris. Though understandable considering the role that Paris has in the highly centralized nation, Weiner believed that Parisian Jewish realities and identity could not be equated with that of French Jews who lived elsewhere in the country-unless proven to be so.

The Dijon Jewish community, defined as those individuals who identify themselves as Jews and participate to some extent in "Jewish" activities, lends itself well to a study of this type. It numbers approximately 225 families within an urban population of about 150,000 (the metropolitan area contains another 100,000). Though relatively small in relation to the general population, the members of the community played, and continue to play, a significant role in the commercial and professional life of the city. Thus, the community is small enough, yet dynamic and important enough, to enhance our understanding of "provincial" French Jews.

Weiner discovered in that spring of 1993 that he had arrived at a unique moment in the community's history. Unlike most Parisian synagogues, or even synagogues in other larger cities, the synagogue center in Dijon represented virtually every major current in French Jewish life, except for the most recent immigrants from the former Soviet Union and Lubavitch Jews (who would, in any case, soon arrive). This blend, combined with a youthful, growing, and active population, resulted in a creative and dynamic atmosphere that marked a significant change from the previous decades of cautious rebuilding after the war and adjustment to newcomers from North Africa.

A major factor in creating this atmosphere was Simon Sibony, the community's rabbi since 1977 and himself a Moroccan immigrant. Although the synagogue was part of the French Central Consistory system, established in the nineteenth century to oversee and represent national Jewish affairs, Sibony resisted the increasingly conservative tendencies of the Paris-based Consistory Council. He remained open, tolerant, and moderate. To cite one example, he permitted women to sit on the main floor of the sanctuarythough behind the men-and encouraged them to participate in non-religious

\footnotetext{
* Robert Weiner, "French Jewish Images of America: The Case of Dijon," Proceedings of the Western Society for French History: Selected Papers of the Annual Meeting XXV (1998): 79-87; Robert Weiner, "On Interviewing French Jews: The Case for Oral History," Proceedings of the Western Society for French History XVI (1989): 316-25; and Robert Weiner, "Perspectives on French Jewry in the 1980s: Crisis and Renewal," Proceedings of the Western Society for French History XIII (1986): 251-6o.
} 
leadership positions within the community. These practices were departures from those prevailing in most Consistorial synagogues.

Another fact that made Dijon distinctive was that, except for the absence of a full-time parochial day school, there existed by the early 1990 a virtual full service community for Dijon's Jews. They had almost every organization that might be found in larger synagogues and even in larger cities. Anyone, including curious Christians, with a desire for religious or secular activities could find something of interest, from serious Talmud study to youth groups, public cultural events, communal trips, B'nai B'rith, and even a Jewish radio station.

This period of growth and activity in Dijon was the result of the conjunction of local and national developments in French Jewish life. At the national level the processing of Holocaust memory and related Holocaust issues was still important, but in other ways a Jewish cultural renaissance was in progress. Parisian Jews and the national organizations they headed were finding public voices and defending the right to be different as a legitimate minority presence in France. Combined with this was the struggle against persistent anti-Semitism and anti-Zionism in the country, as well as support for Israel.

These issues resonated clearly among many Dijon Jews, especially a group of prominent professionals and business people with young families. Creative and active, they joined with older members to energize their community, founding the France-Israel Association (1991), the B'nai B'rith lodge (1991), and Radio Shalom (1993). Their collective goals were to monitor and fight anti-Semitism in all its forms and to support and explain Israel and its difficult and complicated problems to a wider public. They also sought to raise public awareness of the Jewish presence in Dijon, in particular among local officials and politicians.

At this juncture Weiner had not yet decided to begin an oral history of the community. He merely sought to collect data for articles that he might write. For that end he began attending as many religious services and secular community events as possible and keeping a journal of his observations. Since he already was a cantor, trained in the United States, he soon became an active participant in religious services. He then widened his contacts throughout the community, first with Jews with Eastern European backgrounds like himself, and eventually with more recent members with origins in Africa and the Middle East. Following that first extended stay in Dijon in 1993, he visited at least once annually, and occasionally more often, over the following 18 years, including another extended stay in 2000. He became, in effect, an adjunct member of the community, with a wide circle of friends and acquaintances, and was accepted as a trusted insider. 
Weiner's early interviews were more free-flowing and somewhat less directed than the later ones. Most were chronologically based, allowing the subjects to speak about their family backgrounds, childhood, education, etc., before moving on to more directed questions about their Jewish lives, experiences, and views. It was in one such 1993 interview, for example, that he quickly learned that intermarriage was an especially touchy issue and best approached through casual conversation rather than as an interview question.

Weiner's questions covered a broad spectrum: political and religious preferences; perceptions of, and experience with, anti-Semitism; attitudes toward Israel, Zionism, and the United States; and relations with Gentiles, especially with Muslims. He also sought opinions about France's future, particularly about the future of French Jewry. Additional biographical material was included when an individual had an unusual background, such as birthplace, Holocaust experiences, or a known family history stretching back centuries.

Transcribed and translated by a number of talented French-speakers, the tapes of individuals sometimes yielded as many as 120 typed pages, though the norm was usually 40 to 50 pages. The information, as noted above, formed the basis for several academic journal articles as well as conference papers and class lectures. F Fortunately, Weiner's annual visit to Dijon and his extended stays in 1993 and 2000 gave him the opportunity to conduct a number of two- and three-session interviews of about two hours each. The close relationship he maintained with a number of interview subjects allowed him to return to question the same individuals he had first encountered in 1993.

Delays in putting the interviews into print turned out to be fortunate, because significant changes have occurred in the Dijon community in the last few years. The energy and sense of purpose that characterized the early 1990s have given way due, in part, to internal divisions but also because of changing local, national, and international conditions. As a result, further interviews were deemed necessary in order to provide a more complete and inclusive account of the contemporary Dijon community.

Weiner turned to retired Professor Richard Sharpless, a long-time friend and Lafayette College colleague, for assistance. Prior to his academic career, Sharpless had worked as a journalist and editor; although familiar with Weiner's work in Dijon, he provided a useful distance from the project. It was agreed that he would do all of the editorial work, especially on the 3,000 to 4,000 pages of transcribed interviews. Because of the structural problems

\footnotetext{
* Weiner, "French Jewish Images of America"; Robert Weiner, "Pour le meilleur ou pour le pire: The Jews of Dijon in the 1990s, A Memoir," Proceedings of the Western Society for French History: Selected Papers of the Annual Meeting XXIX (2002): 68-75.
} 
involved with the copious earlier interviews (a topic on page 11 reappeared again on page 29, etc.), it was decided to abandon a question-and-answer format for a narrative by each interview subject. Sharpless then reorganized and closely edited the original transcripts and wrote the narratives as they now appear. Every effort was made to retain the voice of the interview subject and the accuracy of what was said.

A decision was made to divide the interviews into three groups that reflect the ways in which Dijon Jews characterize themselves. The first group is composed of members of the synagogue-center community, by far the largest category, which includes a gamut of religious views from traditional orthodoxy to secularism and much in between. Today, this group is comprised of some 170 to 180 families, mostly middle-aged and older.

The second group of about 15 families is the Lubavitch. They also include a range of religious orientations, from Hasidic Lubavitch Judaism to a rather secular couple who placed their son in the Lubavitch school-the group's greatest attraction for young couples.

The third group is comprised of unaffiliated Jews, perhaps 40 to 50 families, who have chosen to remain separate from the established groups for a number of reasons. Generally more assimilated and more liberal, this group even includes several anti-Zionists.

In terms of the general organization of interviews within each group, except for the leaderless group three, we have chosen to begin with leaders, since they offer the best global introduction to each group's functioning, nature, and overall goals. This will afford the reader a coherent and engaging pathway into each group's development, structure, and functioning.

In addition, more sharply focused short interviews were conducted in Dijon during 2000-07, many with previously interviewed subjects. These were designed to update attitudes and opinions about the evolving community. These interviews were ably transcribed and translated by Maria Mitova and Vanida Narrainen, bilingual Lafayette College EXCEL student-scholars. They also completed the tedious task of reviewing the accuracy of the earlier interviews.

Several excerpts from the community journal Mazal Tov complement the interviews. Published several times a year, and continuously-though under various names - since 1978, the journal is an eclectic, excellent source of history and information. It contains articles about topics brought up in the interviews, occasionally written by the subjects themselves. There are opinion pieces, reviews, recipes, announcements, reprints from other Jewish publications, and letters. Though overseen by an editorial board, the views of the editor usually predominate. The current editor, Cathie Bussidan, has 
established and maintained high editorial standards while struggling to keep the publication going during difficult times. It remains an excellent source for study of the community. Numerous longer excerpts from translated copies of the Mazal Tov interviews are published in an E-book format.

Drawing upon copious notes he took during his various trips to Dijon, Weiner co-wrote with Sharpless the historical Introduction and Afterword. Weiner also provided the chronology, glossary, and bibliographies, as well as co-writing the brief biographies that introduce each interview. These, along with a map of the city, provide the reader with a complete picture of the Jewish community of Dijon.

* It is hoped that the first selection of a two-volume anthology of translated Mazal Tov articles will be available by fall of 2012. A second selection of articles, from the late 1970 to 2000 , should be available by the fall of 2013 at http://dspace.lafayette.edu/handle/10385/845 and http://dspace.lafayette.edu/handle/10385/846. 